\title{
Dementia
}

http://dem.sagepub.com/

\section{Self and embodiment: A bio-phenomenological approach to dementia} Stephan Millett

Dementia published online 15 June 2011

DOI: $10.1177 / 1471301211409374$

The online version of this article can be found at:

http://dem.sagepub.com/content/early/2011/06/14/1471301211409374

\author{
Published by: \\ (S)SAGE \\ http://www.sagepublications.com
}

Additional services and information for Dementia can be found at:

Email Alerts: http://dem.sagepub.com/cgi/alerts

Subscriptions: http://dem.sagepub.com/subscriptions

Reprints: http://www.sagepub.com/journalsReprints.nav

Permissions: http://www.sagepub.com/journalsPermissions.nav 


\section{Self and embodiment:} A bio-phenomenological approach to dementia

\section{Stephan Millett}

Curtin University, Perth, Western Australia
Dementia

$0(0) \mathrm{I}-14$

(C) The Author(s) 2011

Reprints and permissions: sagepub.co.uk/journalsPermissions.nav DOI: $10.1177 / 1471301211409374$ dem.sagepub.com

(SAGE

\begin{abstract}
Loss of self is widely regarded to be a consequence of dementia, and this perceived loss presents a variety of problems - not least because a clear understanding of the concept of self is elusive. This paper suggests a way to cut through problems that arise because we rely on conceptions of self in our understanding of the effects of dementia. It is proposed that we can avoid reliance on the concept of self through an approach based in bio-phenomenology. Such an approach would help us better understand the inner life of those with dementia and assist us to recognize that even in late stage dementia they are semiotic subjects with unique value.
\end{abstract}

\title{
Keywords
}

dementia, embodiment, phenomenology, self, semiotic subjects

\section{Introduction}

A perception that people with dementia suffer a loss of self has wide currency and informs both lay and professional understanding of dementia. However, approaching an understanding of dementia from a position based on selfhood or personhood presents a dilemma. In the first horn of the dilemma, if we take a view that people with dementia are in the process of losing their 'self' then the end result of the process of loss is a non-person, that Davis (2004) contends is an 'ontological nullpoint'. If the end result is a non-person and we stick with the standard formulations of ethics then a radical shift in moral relations is entailed as in these formulations our moral relationships to persons are categorically different from moral relationships with entities that do not meet the criteria for personhood (however defined). In the second horn of the dilemma, if we take a view that people with dementia maintain a self we may place an unnecessarily high burden on the untrained family carers who do most of the work of care. The burden includes the following elements: carers are denied a proper mourning for loss of their loved one as the dementia

\section{Corresponding author:}

Stephan Millett, Office of Research and Development, Chancellory Building, Curtin University, PO Box UI 987, Perth 6845, Australia

Email: s.millett@curtin.edu.au 
progresses; they may feel guilt or shame at their changed feelings toward the obviously changing 'person'; and they effectively become complicit in defining those they care for as disabled and as having a progressive deficit (Davis, 2004). That there is no widespread agreement on what a 'self' is and what its loss might constitute adds to the problem. Loss of self is frequently viewed in terms of diminution of cognitive capacity. Those close to a person with dementia, and those with dementia themselves, observe that memory and ability to think clearly both degrade as dementia progresses. But does this mean that there is also a process in which the 'self' is degraded or diminished? That cognitive capacity does diminish progressively in people with dementia is undeniable, but we need to ask whether and how cognitive capacity affects the value of an individual. If we use cognitive capacity alone as a determinant of value we deny relevance to emotion, embodiment and a changing inner life as well as, at a fundamental level, to existence itself. We need also to acknowledge the value of relationships and to find ways to encourage them continuing. People with dementia are still mothers, sisters, fathers, brothers, friends and neighbours. They are part of a continuing narrative shared by others and there is value in the continuing story as well as value in the story continuing.

People commonly take their initial understanding of dementia from a medicalized discourse which views dementia in terms of pathological change (Phinney, 2002). But pathological change itself is not enough to identify dementia because even 'at the most objective end of "mental" illness (that is, in the field of "organic" dementias)... (there is) no hard scientific boundary between disease and normality' (Hughes, Louw, \& Sabat, 2006, p. 2). In this paper I suggest that an alternative explanatory model that avoids the dilemma described above and which is inclusive of relationships may be available by taking an unusual viewpoint with origins in the biological phenomenology of Jakob von Uexküll (1909). This bio-phenomenology was known to the $20^{\text {th }}$ century philosophers Husserl, Scheler and Merleau-Ponty in turn and influenced the way they understood the role of the lived body as a being-in-the world and how, as a result, each of us creates a unique meaningful world. Under this model we can recognize that there is a life-world - or directly experienced world - for people with dementia, who continue to experience the world and create meaning, even in the presence of severe cognitive degradation. It is clear that people with dementia have an affective response to certain stimuli: they laugh, cry, express frustration and disappointment, engage playfully with others, and so on. Affective or emotional responses - signs of happiness, sadness, frustration, anger and the like - are indicators of an interior life the extent of which may not be determinable using cognitive criteria alone. From the affective responses we can infer that people with even late-stage dementia still react to, engage with, and co-create a life-world. And, as Feinstein, Duff and Tranel (2010) showed in a study of people with severe amnesia, it may be that an affective response continues even when there is no memory of the event which initiated it. People with dementia have a life-world and an inner life. This inner life, as we will see below, is the basis of a value that people have that is independent of what others think or feel and independent of cognitive capacity.

\section{Self and personhood}

A perception that people with dementia are in some sense in a process of losing their 'self' appears throughout both the popular and the scientific literature on dementia (e.g. Tappen, 
Williams, Fishman, \& Tuohy, 1999). And the way dementia, in particular Alzheimer's, has been constructed as a disease rather than as an extreme form of an age-related state has contributed to a situation where the subjective experience of ageing is distressing for an increasing number of people and where senility has, in effect, been 'monsterized' (Herskovits, 1995, p. 153) to the extent that people, generally, fear identity loss (MacRae, 2010) in themselves and in others. Kitwood's (1997) person-centred approach to care has made a big difference to the lives of those with dementia, but despite the wide adoption of this approach there continues to be a commonly-held view that as dementia progresses people somehow lose their 'self' and stop being the same person - in effect becoming less of a person. This presents a real problem for the welfare of those with dementia as it can lead to depersonalized treatment (Ashworth, 2003; Kontos \& Naglie, 2006). The person-centred approach to caring for people with dementia is underpinned by the idea that personhood persists into the later stages of dementia. This widely-adopted approach has brought major benefits, but also has costs. For example, Davis (2004) suggests that Kitwood's attempt to preserve a sense of personhood - or 'personswithout-awareness' - in people with dementia can both damage and de-legitimate the feelings of primary carers who no longer see any vestige of their former relationship with the individual they are caring for. Although much has been done to give the best care for those perceived to be suffering loss of their self or their personhood, the question of what constitutes personhood and what might be left of it once dementia sets in has been largely overlooked (Davis, 2004).

To begin to address the issues associated with self and personhood in dementia, we need to understand what a 'self' is and what a 'person' is - a task not as simple as it might seem, despite the fact that these are terms in everyday use. But we need also to distinguish self and personhood from identity, as this adds another layer of confusion.

As Witt, Woopen, Kuhn, Timmerman, \& Zurowski (2011) note, when a woman who has had deep brain stimulation for Parkinson's Disease makes the judgement that 'I am not myself anymore' she 'seems to be saying that she is and, at the same time is not the same individual as before the operation', but 'this would be an overt contradiction'. The person who says 'I am not myself' does not mean to be contradictory, but the claim appears confused. Witt et al. (2001) clarify the sort of confusion underlying this expression through reference to Schechtman's (1996) two questions of personal identity: the 'characterization question' and the 'reidentification question'. The reidentification question refers to numerical identity, which is impossible to change (if $a$ is numerically identical to $b$, then $a$ and $b$ are one and the same thing). The characterization question addresses personal identity in the 'Who am I?' sense and involves 'certain elements and states figuring prominently in a person's mental life' (Witt et al., 2011). The authors distinguish 'personality', as a psychological concept, from the philosophical concept of 'individual identity', which they then focus on. I won't do more with this here other than to note that their distinction adds a valuable clarification of the key concepts addressed in this paper, in which I am primarily concerned to find a way to side-step the difficulties created by the way that in their naturalized, common-use meanings the notions of self, selfhood and personhood are conflated and confused with identity. The confusion is compounded by the terms self, selfhood and personhood often being used interchangeably as, for example, Sabat (1998) notes when he observes that the self perceived as being 'lost' in cases of dementia is most frequently cast in terms of personhood. 
I will explore the notions of self and personhood further but will then use the terms largely as synonyms in part because this reflects the way most people use them and in part because in the following discussion the terms and the concepts underlying them will be put in brackets, so to speak, while consideration is given to whether they are needed.

How the concepts of self and personhood are to be understood is still keenly contested despite a long history of inquiry about them. The nature of selfhood has, since Descartes and Locke, been looked for in three main dimensions: the bodily or material, the relational and the reflective, or some combination of these (Seigel, 2005). If we accept these dimensions, or categories, we are faced with a choice between many possibilities as to what a self might be. We may, for example, pick up on conceptions of the self that require a mind that is aware of its own inner states. We may rely on conceptions based on embodiment - the idea that there is something necessary and special about the body itself. We might include the idea that the self is both partly formed by relationships and shows some part of itself only within relationships with others. We might also take up conceptions that acknowledge the possibility that there can be a self without a body or conceptions where the self can be thought of as 'decentred' in that it lies somewhere between three different 'worlds': 'my' world; the objective world of things as they really are; and the shared or social world ('our world'). Finally, we might settle on David Hume's (1978) famous approach in which there is no self as such, only a bundle of perceptions. However, there are problems whichever approach we take. How are we to know, for example, whether someone in the late stages of dementia is aware that she is aware? And if there is no self, but only a bundle of perceptions, as Hume argued, what is doing the perceiving? These are abstract and possibly strange questions and those involved in everyday care might well wonder what it has to do with them, but these questions can shed some light on problems of practical importance for carers. For example there is the question of whether we should 'give priority to the preferences and attitudes this person held before [their move into dementia] or follow the person's present preferences?' (Jaworska, 1999, p. 108) If we go with the first we in effect deny that the individual with dementia has the same rights to self-determination as do other adults in the community. If we follow the person's present preferences we run the risk of agreeing to something that might not make sense to us or, worse, to something that brings further problems.

In posing the question about preferences Jaworska notes two dominant theoretical perspectives: Dresser's view that preferences expressed earlier should not be taken into account because '[he or she]... is not necessarily the same person as the one who expressed these preferences...' and Dworkin's (1993) position that we fail to take seriously both the autonomy and the well-being of someone with dementia unless we adhere strictly to the person's earlier wishes. Each of these positions reflects a presumption that before the onset of dementia there is an autonomous self possessing cognitive ability and self-awareness and that this self is somehow lost or degraded as dementia progresses. This presumption implies a relation between mind, body and self that goes back to René Descartes in the $17^{\text {th }}$ century, an understanding rejected, in the main, in contemporary philosophy of mind but which still figures in the popular understanding and which remains a strong influence on how we understand loss of self in dementia.

Dresser acknowledges that there may be an autonomous self, but a somehow different one. What do we mean when we say someone is not necessarily the same person as they were before their dementia began? Is a man or woman at 18 the same person as at 21 , at 41 , at 61 ? 
Do we give someone a different moral status because they are 61 and not 21 ? Of course, there are differences in our views, our outlook, the way we look - life changes us - but even in the event of illness, in so called life-changing experiences, we continue to occupy a body that has a unique (numerical) identity despite the changes it undergoes. And we continue to be part of a social narrative: we are each part of a story that involves others. Dworkin's view seems to deny that the person with dementia has autonomy and has ceased altogether to be able to express preferences. Preferences change and - in the absence of other factors, such as the need to prevent unnecessary harm - to deny someone with dementia the satisfaction of a preference they now have fails to treat them with respect.

There are good reasons not to rely on a sense of self (or personhood) that depends on cognitive capacity and on a separation of mind and body. One significant problem arises because, as the ability to think, understand, remember and act diminishes, the 'self' is also thought to begin to disappear and what is left is regarded increasingly only as a body. There is also considerable and continuing philosophical, psychological and psychiatric debate as to what a self is and how it relates to personhood. For Morrison (1994, pp. 550-551), for example, persons are individuals to which we attribute thoughts, beliefs, desires, emotions, intentions, memories, sensations, and intentional actions - together with responsibility for those actions,' but attributing mental properties to persons 'give(s) rise to the idea that a person is something "over and above" a material body.' What that 'over and above' consists in and how it relates to the body is problematic. While the possession of personhood is frequently regarded as all that is needed for something to be morally considerable, reliance on the concepts of self and personhood has problems and it is worth reconsidering whether a concept of self and personhood that relies on cognitive properties is necessary, or even helpful. We should also ask, what moral standing comes with the possession of cognitive properties? If Beauchamp (1999) is right, and there is good reason to suppose that he is, then no set of cognitive properties confers moral standing and we need to look for other sources of moral value.

Throughout history there has been a vigorous discussion of how to regard the concept of self (and personhood). In addition to the popular understanding of an individual autonomous agent which maintains its identity over time, has cognitive capacity and which is aware of its own existence, there have been numerous ways to view the self. For Nietzsche, Heidegger, Duchamp, Foucault and Derrida, for example, the independence and autonomy claimed of the self in the Western tradition is an illusion (Seigel, 2005, p. 5). Or it may be, as Taylor (1989) argues (following Merleau-Ponty), both that knowledge comes about from embodied experience and that individuals arise in the context of a society. This idea of knowledge arising from embodied experience in social environments, picked up by Kontos $(2004,2005)$ and explored further below, is an important counter to the belief that loss of cognitive function leads to loss of self, but is not the only approach in the dementia literature that moves beyond the notion of the classical autonomous individual. For example, Sabat and Harrés (1992) social constructionist approach names two views of self, 'self', (the self of personal identity) and 'self", (multiple public personae) and Herskovits (1995, p. 159) notes five models of self in all of which 'the status or viability of the "self" is disentangled from cognitive ability' and 'the relational self supersedes the autonomous self of classical liberalism'.

The key issue with respect to dementia is that we perhaps should no longer regard the process of dementia as involving loss of self - whatever that is - and to look to ways to understand what dementia might be like from the inside, so to speak. 


\section{Embodiment}

The fact that all of us have bodies is obvious, but that fact is important for a number of reasons. The notion of an embodied self repays close attention, but as will be clear in the discussion below, ultimately embodiment itself may be the primary issue. Social factors are clearly important, but also, as discussed below, it is possible to re-envisage them under a particular way of understanding how we communicate with and make sense of the world around us.

To understand the importance of embodiment and individuals' engagement with the world, it pays to go back to the $18^{\text {th }}$ century and David Hume. In his Treatise Hume (1978) argued that we do not have any idea of 'self, after the manner it is here explain'd' (Hume, 1978, p. 251) but rather all of 'mankind... are nothing but a bundle or collection of different perceptions, which succeed each other with an inconceivable rapidity' (Hume, 1978, p. 252). The mind is 'a kind of theatre, where several perceptions successively make their appearance' and which has 'no simplicity... at one time, nor identity in different' (Hume, 1978, p. 253). The mind is not one thing and cannot be said to be the same in any sense at different times. There is no 'mind' to which numerical identity can apply. Importantly for the discussion that follows, Hume considered perception to be fundamental, as this oft-quoted passage shows:

For my part, when I enter most intimately into what I call myself, I always stumble on some particular perception or other, of heat or cold, light or shade, love or hatred, pain or pleasure. I never can catch myself at any time without a perception, and never can observe any thing but the perception.

(Hume, 1978, p.252)

If we follow Hume we can come to a very different understanding of what an individual is from that which has arisen from Descartes' separation of mind and body and which still has a dominant place in popular understanding. This has important ramifications for our understanding of people with dementia, for if there is no 'self' with either simplicity at one time or identity at another and we are but bundles of perception then what can we say is being lost as dementia progresses? And if there is no set of cognitive properties that confers moral standing, as Beauchamp (1999) argues, then diminution of cognitive capacity should not alter the moral standing of an individual.

An understanding based on the idea of a self that is worth pursuing further comes from Kontos (2004, 2005), who integrates Merleau-Ponty's conception of self as an embodied being-in-the-world with Bourdieu's habitus and advocates a notion of embodied selfhood that is a 'complex inter-relationship between primordial and social characteristics of the body' which 'reside below the threshold of cognition' (Kontos, 2004, p. 837) and which 'are enacted at a pre-reflective level' (Kontos, 2004, p. 841). She recognizes two origins for this selfhood residing in the pre-reflective body, 'the first is primordial whereby selfhood emanates from the body's power of natural expression, and manifests in the body's inherent ability to apprehend and convey meaning' (Kontos, 2004, p. 837) and the second is the sociocultural dimension of the pre-reflective body. In this view, corporeality (embodiment) is active, necessary and primary in sustaining selfhood, a view built on Merleau-Ponty's understanding of the body's embeddedness in the lived world, a world of which the body makes sense through its sensory perception apparatus. Kontos' expression of the embodied nature of self, through her beautiful observations of the residents of the dementia care 
facility she calls 'Chai Village', leads her to suggest that if there could be a general recognition of the way humans are embodied, 'it would critically challenge the widespread presumption of the loss of agency with cognitive impairment' (Kontos, 2004, p. 846). This would have important implications for the way people with dementia are treated, and would likely provide greater insight for carers.

But even if selfhood is a mix of primordial and social characteristics, are we any further advanced? Does this help us understand dementia any better? We can continue to ask whether the self should be considered as separate from a body, as a part of the body, as part of a whole of which the body is also part, or whether there is a non-causal (supervenient) relationship between the self and the body in the same way that, for Lewis (1986), mental respects supervene on physical respects. Given the complexities inherent in conceptions of selfhood and personhood and the widespread misunderstanding of the concepts, should we, as the discussion below suggests, leave aside notions of self and personhood and focus on the continuity over time of an embodied individual and our attitude to that individual?

\section{Personhood is not a necessary consideration}

When someone caring for a person with dementia begins to perceive a loss of 'self' (or personhood) in those they care for, there are frequently implications for the kind of care being given and consequently for the welfare of the person with dementia. However, focusing on personhood, particularly on a notion of personhood based on the presence of cognitive ability, is not the only approach possible and may not be the most helpful approach. The predominant view of self (and personhood) in the community, and the one that is ordinarily called to mind when we are told there is loss of self in dementia, can be traced to Descartes' claim that body and mind are each distinct types of substance, the one having a physical presence and the other with no physical form. However, if we move away from this view and regard the 'person' with dementia as a 'whole' and as having a changing 'inner life' then he or she can come to be regarded, in Ashworth's (2003) terms, as an individual 'of infinite consequence simply by virtue of their individual existence'.

We have been looking at what a 'person' is from a philosophical perspective, but whether or not people with advanced dementia should be considered persons in the philosophical sense (because they no longer meet certain criteria, such as being aware that they exist and being able to communicate, plan for the future and act on those plans) they are still able to make meaning through sensory interactions with the world around them. They still perceive actions, language and sensations of various kinds and retain an agential relationship with the world (they can do things) - however different that relationship may be from others without dementia. What if we were to leave aside personhood as a criterion of considerability (put it in brackets, as it were)? One effect would be that we could focus on the idea that there is a being with an inner life confronting us, a being with value simply because he or she has a 'life-world' - a constructed meaningful world revealed to him or her through their senses.

This idea of life-world comes from the philosophical tradition of phenomenology. This tradition has a number of strands, but at its foundation is the idea that through its experiences a being creates its own relationship with the world around it. We can add to this the idea that this relationship is based on the interpretation of signs which are received via biological structures, such as ears, eyes, nose, mouth and skin. Signs here might be sights, sounds, smells or touch sensations and will include such things as words and body language - all signs that people with dementia continue to interpret in their own way. Much of 
phenomenology has focused on human ways of being in the world; however, if we refer to the phenomenology of animal ways of being in the world we can begin to move away from a problematic reliance on notions of human self and personhood when trying to understand the life-world that people with dementia continue to create. While rejecting strongly any claim that people with dementia are somehow non-persons or in some sense lesser beings than cognitively competent humans, going back to a concept of life-world from animal biology offers a useful way to understand the importance of embodiment and individuality to the world of those with dementia and a useful way of understanding how they continue to have value, both for themselves and for others.

The idea of a biological phenomenology takes perhaps its most important form in the work of Jakob von Uexküll (1909) and his notion from early last century that animals create an Umwelt or meaningful surrounding world through the interaction of their sensory receptors and the physical world around them. The term Umwelt was used late in the 19th century by Edmund Husserl, and although he later replaced it with Lebenswelt the terms are near synonyms (Chebanov, 2001; Gurwitsch, 1956). Von Uexküll's (1909) work on Umwelt theory influenced the phenomenology of the important $20^{\text {th }}$ century philosophers Max Scheler, Martin Heidegger and Maurice Merleau-Ponty (Buchanan, 2008; Gare, 2008; Merleau-Ponty, 2003; Scheler, 1970, p. $32 \mathrm{n}$.) and is commonly held to be the first statement of what is now called bio-semiotics (Deely, 2004; Sebeok, 1999). Von Uexküll (1909) uses a concept of world derived from Immanuel Kant's position in the Critique of Pure Reason that the human world is 'interpreted in such a way as to correspond to, and even be constituted by, the structure of man's understanding and cognitive powers' (Weiss, 1948, p. 49). In effect, he takes the idea that we cannot know things in themselves and applies this beyond the human. We cannot know things in themselves, as they really are, because our knowledge is always secondhand in that we get knowledge from our senses and not from the thing itself. There may be something in front of us, but we only know how it appears to us based on information received. Take an apple, for example. It may appear red to me, but not to someone who is colour-blind; it may taste sweet to you, but to me it is tart because my body reacts to the salicylic acid in the juice. To a goat it is probably simply something to be eaten. To an artist it is something else, and so on.

For von Uexküll (1909), like humans, other organisms cannot have unmediated access to things in themselves, but make 'sense' of the world in species-specific ways that depend on the complexity of their internal structures, such as their sense organs or, more generally, their internal chemistry. For him, all organisms have both an inner and an outer world and both are subjective worlds. The inner world, what he calls the Innenwelt, arises from the communication between the components of an organism, e.g. between the cells themselves or between the sense organs and the brain. The organism and the outer world sensed by it form an interactive unity, an Umwelt, or a sort of perceptual bubble. Every representative of every species of protist, bacteria and animal has its own Umwelt (Krampen, 2001, p. 419) that it is always actively creating as it reacts distinctively to signs from the physical world. Their internal systems - at whatever level of complexity - allow organisms to interpret signs from the outer world. In von Uexküll's (1909) primary example, a tick responds to butyric acid on the bodies of mammals and to warmth. It climbs up a plant and when it senses butyric acid it drops. If it lands on a mammal it then moves to the warmest places, where blood vessels are closest to the skin and starts to suck blood. Although not conscious of doing so, the tick 'interprets' the sign of butyric acid and the sign of warmth. Semiotics is the study of signs and organisms have the basics of a semiotic relationship with the external 
world - object, interpreter and sign. This semiotic relationship allows the organism to create for itself a unique semiotic niche the nature of which is defined by its own structure. Simpler organisms have fewer receptor cells than more complex organisms and the complexity of the sense world of a simple organism is much less than that of a mammal or other more complex organism. In essence, more complex organisms occupy a larger semiotic niche than simpler organisms. That is, the more complex an organism, the more signs it is capable of receiving and interpreting and the greater its possible sphere of influence: the more complex an organism the more there is going on in its Innenwelt and the larger is its Umwelt.

More complex organisms have a greater potential to interact with their environments because they have more receptors through which to receive signals and greater internal capacity to interpret these signals. But, does greater capacity imply greater value? The actual interaction with elements of their environment also gives each organism what may be thought of as an ecological niche value, which is a statement of their value to other organisms. The ecological niche value of humans includes their social interactions with other humans. The actual interaction of an organism with its environment is governed by the capacity or potential it has to interact. This capacity or potential can be thought as being 'built in' to the organism, it is an essential component of what it is. As such, this capacity can be thought of as an ontological niche value. Taking into account ontological niche, semiotic niche and ecological niche we see that more complex organisms occupy a richer phenomenal 'space' than less complex organisms. Such organisms may or may not have a greater intrinsic value as a result, but the total niche occupied by a more complex organism is larger than that occupied by less complex organisms. People with dementia continue to be complex beings who occupy an ontological niche, a semiotic niche and an ecological niche each of which can be viewed in terms of individual qualities and through the continued role they play in the lives of others. Their semiotic niche is not limited to verbal and non-verbal communication, but relates primarily to their continuing ability to interpret signs from their immediate environment. The interpretation of signs in the general sense meant here is not necessarily a mental activity, but involves bodily reactions of all sorts, to inputs from a range of external sources such as reactions to heat and cold, to smells, sounds and sights. People with dementia - even severe dementia - continue to have the capacity to interact with their environment and, simply because they have a body and the capacity to interact, they clearly occupy an ontological niche. Included in their ecological niche value are the interpersonal relationships they have now as well as those they have had and those they will have. People with dementia continue to be participants in and co-creators of the lived lives of others, whether those others are paid carers, relatives or friends. In short, just like people who do not have dementia, they continue to be active subjects who create meaning for themselves as they encounter the external world. As Merleau-Ponty explained in his lectures on nature, von Uexküll's (1909) concepts are central to understanding this:

The higher animal ... constructs an Umwelt that has a Gegenwelt, a rejoinder in its nervous system. In his work in 1934, Uexküll specifies this notion of Gegenwelt. He distinguishes the Welt (the objective world), the Umwelt (the milieu tailored to the animal), and the Gegenwelt, which is made up of two systems: the Merkwelt and the Wirkwelt. The Merkwelt depends on the way in which the sense organs are made. These realize a classification of stimuli according to a disposition proper to the animal. The Merkwelt is a 'grill' interposed between the animal and the world. In order to determine the world of the animal, we have yet to make the Wirkwelt 
intervene; that is, the reactions of the animal in the milieu, the melodies of impulses. In order to grasp the world of the animal, we must not only make perceptions intervene, but also behaviours, because these deposit a surplus of signification on the surface of objects.

(Merleau, 2003, p. 172)

The ability to create an Umwelt through reactions to the milieu and various impulses, which we might call making meaning through bio-semiosis, is a centrally important element of what it means to be alive. The reduced capacity of people with dementia to interact with the world may diminish the scope of their ontological niche, and may even be a symptom of what Davis (2004) describes in his discussion of the ontological nature of the experience of dementia as 'the very splintering of the sedimented layers of Being' (Davis, 2004, p. 375) but it cannot be said, as he does, that the 'life-world dissolves into background meaninglessness' because the body itself continues to make meaning through its sensory apparatus. Those with dementia continue to occupy ontological, semiotic and ecological niches and with this comes value. The value associated with occupation of an ontological niche is, however, categorically different from the more instrumental values of the other niches occupied. This ontological niche value ensures that those with dementia continue to be valuable, continue to be morally considerable and continue to impose an obligation on others to ask 'How can I help you?' even - at the extremes of dementia - in the absence of an ability to respond.

How does value accompany the occupation of an ontological niche? Here we need to turn to Aristotle and the position that with each living thing the ontological quality of beingfor-itself enters the world. In Aristotelian terms each living thing has an immanent telos and an endeavour to persevere in its own being. The telos is a sort of non-conscious goal that is an essential part of what something is. For example, the telos of an acorn is to become a mature oak tree. In the absence of anything to stop it, an acorn will grow into a mature oak tree. The endeavour to persevere in being is variously called nisus or conatus in documents post-dating Aristotle, but both concepts ultimately derive from Aristotle's concept of dünamis which at De Anima, II.4 is described as a set of active capacities (dünameis) that direct life's activities (Millett, forthcoming). Following Aristotle, individual living things bring value into the world because each has internal directiveness (telos) and a good-ofits-own and is at the very least self-valuing - i.e. each has its own end or purpose within it, an end that it has an interest in achieving. Each living thing has an interest in maintaining itself as an organism and thereby values itself - although this is not a conscious valuing. But why should we take that particular value into account? One reason is suggested by Hans Jonas (1984) who takes a newborn to be the object of responsibility in what he calls the paradigm case of 'natural' responsibility. Following Aristotle's notion of immanent telos, the newborn has value-for-itself. It is not a mere existent. The newborn is 'the perfect paradigm, literally the prototype, of an object of responsibility' and its mere being makes a moral demand on us (Jonas, 1984, p. 131). Any moral agent coming into contact with the newborn child has a responsibility to care for the child because the child-as-object has a good that carries with it an immanent (or indwelling) demand continually to be realized. In Jonas' words, the newborn's 'mere breathing uncontradictably addresses an ought to the world around, namely, to take care of him. Look and you know... the plain being of a de facto existent immanently and evidently contains an ought for others' (Jonas, 1984, p. 131). There are obvious differences between newborns and people with dementia, but also some clear parallels that are morally relevant. Like a newborn, a person with dementia 
has value-for-itself simply because he or she is human. People with dementia, like newborns, are particularly vulnerable to harm from the world and this vulnerability coupled with the value they have in themselves places the rest of us under an obligation to take care of them. But there is more to this story and I would like now to turn briefly to Emmanuel Levinas because there are several issues relevant to the way we regard people with dementia that should be raised even though space does not permit them to be discussed in any detail. Emmanuel Levinas was, like Jonas, a student of Heidegger. And, like Jonas, Levinas also comes to the conclusion that each human addresses an ought-to-care to each other human. Of particular interest, however, given the previous discussion of embodiment are Levinas' arguments about the somatic (bodily) basis of subjectivity and ethical relatedness. For Levinas (1981) subjectivity is not subjectivity at the level of personal consciousness, but is situated at what Krueger calls the 'bedrock of human reality: the locus or place of contact where self and world, interiority and exteriority, meet and interpenetrate' (Krueger, 2008, p. 606). To understand this we need to understand Levinas' use of the concept of sensibility and its relation to subjectivity. Sensibility operates at the pre-cognitive level and is that which allows the interpenetration of self and world and interiority and exteriority. Subjectivity originates at the pre-reflective level of the animate body and is not given but [is] rather emergent: a dynamic and temporally-extended process, continually in-the-making via the body's active engagement with the world' (Krueger, 2008, p. 606). Subjectivity is embodied and is there with or without cognition being present. People with diminished cognitive capacity continue to engage as subjects in a life shared with others. Levinas' ethical position hinges on there being both an embodied and socially-embedded subjective life and an a priori obligation to offer help to others. The important issue for an ethics of dementia care influenced by Levinas is that each of us has an obligation that exists before we encounter any particular embodied and socially-embedded other. We must act on that obligation when we come face-to-face with someone. The obligation we are under, at its simplest, is to ask 'How can I help you?' and then to act in the other's interests. The obligation is there whether an answer is forthcoming or not.

To summarize, following Aristotle and Jonas, each living thing has a unique noninstrumental value-for-itself and, following Aristotle, Jonas and Levinas, each human being announces an ought-to-care to the world that places each of us under an obligation to help that being.

Subjects are embodied, but is embodiment itself enough so that we do not have to rely on a notion of self in order for us to recognize moral value in, and moral obligation to, others? It may be, as Kontos (2004) claims, 'that selfhood is embodied and characterised by an observable coherence and capacity for improvisation that is sustained at a pre-reflective level by the primordial as well as the socio-cultural significance of the body' (Kontos, 2004, p. 831), however, as noted above, the notion of self is understood and used in many ways and embodiment is common to all living things. The frequent equivocation or confusion of meaning in the use of 'self' suggests that it may be worth taking another approach, and an approach based in the concepts of Umwelt and bio-semiosis presents a good case for consideration. Through the concepts of Umwelt and bio-semiosis we can understand how an individual creates a meaning-full world. The created meaning-full world is built of those signs from its world that it is able to perceive. Among the signs are those from other living things with whom it engages in reciprocal sign-sharing. In humans this would include the way we hear, smell, taste and feel, the way we use language and gestures and the way we interpret such outward signs as dress. 
Semiosis at its most general is necessary for the creation of a social world - whether for humans or any other group of animals. However, the semiosis evidenced in cognitive activity and language is but part of a broader field and it may be that the linked concepts of Umwelt and bio-semiosis are enough for us to understand the life-world of those with dementia. If we employ the notions of Umwelt and bio-semiosis rather than, say, Kontos' (2004) combination of Merleau-Ponty's concept of embodiment and Bourdieu's habitus we can avoid problems related to the equivocal uses of 'self'. The situatedness of an animal (or human animal) in its physical and social milieu may be understood through the concept of Umwelt - the perceptual bubble produced through sensory interaction with objects in the world - and a process of semiosis, of which human language is part, and on which our creation of a habitus depends. By employing the concept of bio-semiosis we can acknowledge, with Sabat (2005), that people with dementia are semiotic subjects - that is, they are 'driven by meaning' - but without committing to cognition-reliant definitions of selfhood and intentionality.

If we do not move away from a view of dementia based in loss of self not only is there, in existential terms, the danger of an inevitably bleak conclusion for those with dementia, but there will also be a bleak outlook for relatives who, having been enlisted in the 'retrieving of a person long since gone,' are denied legitimate mourning for their loss (Davis, 2004). On the other hand, moving away from a view of dementia in which the self is disintegrating has the potential to provide some solace to family carers. If family carers can be helped to let go of the idea of the 'person' with dementia as an ontological unity in decay and understand that their loved one is, in effect, continuing the process of creating a life-world through the changed perceptions that come with dementia then they may be able to manage what Davis calls a 'guiltless grieving' while continuing to provide respectful care. However, if we do move to a position, such as that based in bio-phenomenology, in which we do not rely on a notion of self, what attitude might best we take to those with dementia, most particularly advanced dementia? One candidate is sympathy, as construed by Stephen Darwall.

Sympathy in Darwall's view is felt from the perspective of one-caring: the key issue is that concern is for the other's sake. This concern or desire for something 'for someone's sake' is a 'a form of desire that springs from care' whereas imaginatively sharing a person's concerns (such as one would experience in empathy) 'is hardly the same as sympathy for her' (Darwall, 1998, p. 263). An action based in this sort of sympathy would be a benevolent action.

It may be that sympathy in carers can be triggered by helping them to understand more about the inner life of people with dementia, to help them understand that people with dementia continue to perceive and feel and continue to create a life-world and that with this continuing engagement in the creation of their world, they cannot become, as Davis (2004) contends, an 'ontological nullpoint'.

If carers are helped to understand the inner life of the person with dementia, to look at them from the inside out, so to speak, they will be more likely to act for the sake of the individual with dementia, and exercise sympathetic care.

\section{References}

Ashworth, A. (2003). The lifeworld as phenomenon and as research heuristic, exemplified by a study of the lifeworld of a person suffering Alzheimer's Disease. Journal of Phenomenological Psychology, 34(2), 179. 
Beauchamp, T. (1999). The failure of theories of personhood. Kennedy Institute of Ethics Journal, 9(4), 309-324.

Buchanan, B. (2008). Onto-ethologies: The animal environments of Uexküll, Heidegger, Merleau-Ponty, and Deleuze. Albany, NY: State University of New York Press.

Chebanov, S. (2001). Umwelt as life world of a living being. Semiotica, 134, 169-184.

Darwall, S. (1998). Empathy, sympathy, care. Philosophical Studies, 89, 261-282.

Davis, D. H. J. (2004). Dementia: Sociological and philosophical constructions. Social Science and Medicine, 58, 369-378.

Deely, J. (2004). Semiotics and Jakob von Uexküll's concept of Umwelt. Sign Systems Studies, 32(1/2), $11-34$.

Dworkin, R. (1993). Life's Dominion. New York: Alfred A. Knopf.

Feinstein, J. S., Duff, M. C., \& Tranel, D. (2010). Sustained experience of emotion after loss of memory in patients with amnesia. Proceedings of the National Academy of Sciences of the United States of America (early edition), 1-6.

Gare, A. (2008). Approaches to the question 'What is life?': Reconciling theoretical biology with philosophical biology. Cosmos and History: The Journal of Natural and Social Philosophy, 4(1-2), 53-77.

Gurwitsch, A. (1956). The last work of Edmund Husserl. Philosophy and Phenomenological Research, 16(3), 380-399.

Herskovits, E. (1995). Struggling over subjectivity: debates about the 'self' and Alzheimer's disease. Medical Anthropology Quarterly, 9(2), 146-164.

Hughes, J. C., Louw, S. J., \& Sabat, S. R. (2006). Seeing whole. In J. C. Hughes, S. J. Louw \& S. R. Sabat (Eds.), Dementia: Mind, meaning, and the person. Oxford: Oxford University Press.

Hume, D. (1978). A treatise of human nature, 2nd edn. Oxford: Clarendon Press.

Jaworska, A. (1999). Respecting the margins of agency: Alzheimer's patients and the capacity to value. Philosophy and Public Affairs, 28(2), 105-138.

Jonas, H. (1984). The Imperative of Responsibility. Chicago: University of Chicago Press.

Kitwood, T. (1997). Dementia reconsidered: The person comes first. Buckingham: Open University Press.

Kontos, P. C. (2004). Ethnographic reflections on selfhood, embodiment and Alzheimer's disease. Ageing \& Society, 24(06), 829-849, doi:10.1017/S0144686X04002375.

Kontos, P. C. (2005). Embodied selfhood in Alzheimer's disease: Rethinking person-centred care. Dementia, 4(4), 553-570.

Kontos, P. C., \& Naglie, G. (2006). Expressions of personhood in Alzheimer's: moving from ethnographic text to performing ethnography. Qualitative Research, 6, 301-317.

Krampen, M. (2001). No plant-no breath. Semiotica, 134(1/4), 415-421.

Krueger, J. W. (2008). Levinasian reflections on somaticity and the ethical self. Inquiry, 51(6), 603-626, doi: $10.1080 / 00201740802536662$.

Levinas, E. (1981). Otherwise than being (A. Lingis, Trans.). Pittsburgh, PA: Duquesne University Press.

Lewis, D. K. (1986). On the plurality of worlds. Oxford: Basil Blackwell.

MacRae, R. (2010). Managing identity while living with Alzheimer's Disease. Qualitative Health Research, 20(3), 293-305.

Merleau-Ponty, M. (2003). Nature: Course notes from the College de France (R. Vallier, Trans.). Evanston, IL: Northwestern University Press.

Millett, S. (forthcoming). Aristotle's powers and responsibility for nature. Bern: Peter Lang.

Morrison, K. (1994). The self. In S. Guttenplan (Ed.), A companion to the philosophy of mind (pp. 550558). Oxford: Blackwell Publishing.

Phinney, A. (2002). Fluctuating awareness and the breakdown of the illness narrative in dementia. Dementia, 1(3), 329-344, doi: 10.1177/147130120200100305. 
Sabat, S. R. (1998). Voices of Alzheimer's disease sufferers: A call for treatment based on personhood. The Journal of Clinical Ethics, 9(1), 38-51.

Sabat, S. R. (2005). Capacity for decision-making in Alzheimer's disease: Selfhood, positioning and semiotic people. Australian and New Zealand Journal of Psychiatry, 39, 1030-1035.

Sabat, S. R., \& Harré, R. (1992). The construction and deconstruction of self in Alzheimer's disease. Ageing and Society, 12(4), 443-461.

Schechtman, M. (1996). The constitution of selves. Ithaca, NY: Cornell University Press.

Scheler, M. (1970). The nature of sympathy (P. Heath, Trans.). New York, NY: Archon Books.

Sebeok, T. (1999). The sign science and the life science. Applied Semiotics, 3(6/7), 85-96.

Seigel, J. (2005). The idea of the self: Thought and experience in Western Europe since the seventeenth century. New York, NY: Cambridge University Press.

Tappen, R., Williams, C., Fishman, S., \& Touhy, T. (1999). Persistence of self in advanced Alzheimer's Disease. Image. Journal of Nursing Scholarship, 31(2), 121-125.

Taylor, C. (1989). Sources of the self: The making of modern identity. Cambridge: Cambridge University Press.

Uexküll, J., \& von, X. (1909). Umwelt und Innenwelt der Tiere. Berlin: J. Springer.

Weiss, H. (1948). Aristotle's teleology and Uexküll's theory of living nature. The Classical Quarterly, 42(1-2), 44-58, doi: 10.1017/S0009838800028251.

Witt, K., Woopen, C., Kuhn, J., Timmerman, L., \& Zurowski, M. (2011). Deep brain stimulation and the search for identity. Neuroethics, doi: 10.1007/s12152-011-9100-1.

Stephan Millett, BEcon BA(Hons) PhD, is Associate Professor, Curtin University, Perth, Western Australia. Stephan Millett is presently ethics adviser to the Faculty of Health Sciences at Curtin University in Perth, Western Australia and Chair of the University Human Research Ethics Committee. He received his $\mathrm{PhD}$ in Philosophy from Murdoch University in 1997. For seven years following this he taught philosophy at an independent school in Perth and was instrumental in developing a course in philosophy and ethics which is now part of the curriculum for the final years of school in Western Australia. Prior to this he was a journalist and journalism academic. He returned to a university career in 2004 as the foundation director of the Curtin University Centre for Applied Ethics and Philosophy. His research interests are in professional and applied ethics, health ethics and phenomenology. The key idea for the article in this issue grew from work that will be included in his forthcoming book Aristotle's Powers and Responsibility for Nature to be published by Peter Lang. Address: Curtin University, Kent Street, Bentley 6102, Perth, Australia. [email: s.millett@curtin.edu.au] 